\title{
THE SANCTION OF INTERNATIONAL LAW
}

If lawyers have been discussing this question quite continuously for several centuries the fact that they have reached no solution or agreement thereon is both interesting and significant; interesting because a great unsolved problem must ever lure acute minds to renewed efforts, and significant because we ask ourselves why so much thought has seerned to result in so little certainty. The reason for this, I am forced to conclude, is because the question itself is not a legal question at all. Such a suggestion might savor of temerity were it made by a mere layman; but for one of the profession it may be permissible at times to suggest our own limitations.

The question of whether international law is law, and what constitutes law, belongs in fact to the domain of psychology. As well ask the ord nary mathematician to expound the value, relative or absolute, of the laws of mind or of nature, or the ordinary physician to reply to the question: "What is life?" The fact that the mathematician deals with axioms and postulates and the physician with the living organism, does not qualify them to dogmatize regarding the underlying philosophy of either.

It thus requires a broader view than that which the mere lawyer qua lawyer usually possesses to answer the question: "What is international law?" Some rules of more or less general observance have long existed, but the exact definition and delimitation of these rules and how far they may be law, in the ordinarily.accepted sense of that word, it is difficult to say. International law was supposed, by many thinkers a generation ago, to have no sanction because of the prevailing Austinian theory regarding the nature of municipal law. Lawyers thought an Act of Parliament constituted exclusive material from which to deduce a definition of law, forgetting that only a small part of the law was in the form of statute and that English law antedated not only Parliament, but the kingship.

The fact seems to be that there is little real difference between national and international law as to its sanction. Municipal law 
may be and frequently is violated and so is the law of nations, but in either event, there is some risk in so doing. If the nations do not ultimately enforce some of the law to which they have assented, this lack of enforcement is often true of statute and municipal law generally.

International law is that body of rules which is so far assented to and so far enforced that it deserves the name of law; it is something which connotes a certain regularity of human conduct, induced not by necessary sequences of nature, but by human volition. It is not necessary, to make international law, that all members of the family of nations shall have assented thereto, but the dominant nations at least should do so.

The utmost possible field of arbitration is necessarily coterminous with that of law. Where there is no law, there may be a settlement of an international dispute, but it will be reached through diplomatic channels and not through judicial tribunals. The cause of arbitration may be injured rather than aided by an unrillingness or inability to understand this necessary limitation of its scope. There can be no arbitration where there is either no law or no adequate law to meet the case. Parties cannot arbitrate matters which cannot be stated in terms of law. The effort to extend the field of arbitration must go hand in hand with the endeavor to widen the scope of international law as it now stands, as well as to better existing law by placing it on the basis of a broader morality. The inability of pacificists generally io recognize this situation retards the cause of peace.

The use of force in the ftwentieth century cannot be justified at the bar of public opinion unless it can truthfully predicate a moral basis. Our most noted naval historian and ei sinent publicist, Admiral Mahan, says:

"Hence, the recognition that, if force is necessary, force must be used for the benefit of the communily, of the commonwealth of the world. This fundamental proposition is not impaired by the fact that force is best exercised through law, when adequate law exists, except as the expression of right law is an incubus. Hence, much of the present magnification of law is mere fetich."

This doctrine may well be termed the trusteeship of force. In illustration of his proposition the distinguished Admiral cites the 
Monroe Doctrine. The purpose of the Holy Alliance to restore Spanish domination in South America, was not, as he argues, in contravention of law as it was then, or even now is. Legally, the right to coerce South American states might not, as a legal proposition, have been questioned by the Lnited States, but the law of self-preservation and of the right to develop our own civilization untrammelled by dangers incident to the conflict of the old world, justified the United States in refusing to allow other nations the exercise of the generally admitted right toacquire territory whenever that acquisition was on the American continent.

I cannot quite assent to the correctness of the Admiral's analysis of the situation. This is scarcely a case of imperfection or inadequacy in the law, but rather an instance in which a general rule becomes inapplicable to certain particular conditions, because in conflict with a paramount national policy.

\section{Admiral Mahan says:}

"The relations of interdependent states are not susceptible of full establishment, nor of all necessary adjustment from time to time, upon a basis of law."

As long as special national policies prevent the exercise of their full legal rights on the part of other nations in certain respects, the nation professing such non-legally recognized policies is forced to maintain them against those who seek to carry out their legal rights to the full. This necessitates armament. Such a cause of possible war is not legally avertable. To minimize that danger, we must work for acquiescence in such policy, when just, by the other nations, and this can be done only through diplomatic channels and the education of public opinion. Where controversies of this character arise, as in the case of the Guiana-Venezuela boundary, we can only rely upon a peace sentiment so strong that diplomacy may have time to adjust questions which cannot be submitted to judicial determination until the conflict between law and national policy is settled.

The causes of modern war are often said to be commercial. This is true in a superficial sense only. Commercial friction and commercial ambition may indeed be the proximate causes, but they are not the real and ultimate causes. There can be no war today where the temper and sentiment of the people is not such that 
they can be inflamed into a general passion. The day for the hiring of Hessians to shout strangers with whom they have no possible cause of quarrel, at the mere behest of a ruler, has long gone by.

The gorernments of teday cannot make war in defiance of public opinion, nor is there the slightest chance of their taking so great a responsibility. The danger is that they will be overridden and that their diplomatic efforts will come to naught because of the kindling of patrivtic enthusiasm which over-rides the desires of the government. Jingoism usually proceeds from below, up, not from above, down.

Yet the fact that war between two nations is quite possible, does not make it inevitable. For instance, nuthing seems more improbable than a war between Great Britain and the L'nited States. No serjous conflicting interests are involved. Both nations are satisfied with the slatus quo in regard to territory on this continent. Admiral Mahan considers it unthinkable. But we must remember, as a warning and a safeguard, the strong antipathies of the past which have sunk largely into the subconsciousness of both peoples. The traditions of the conflicts of the Revolution, of the War of 1812 , of the mutual animosities stirred up during our Civil War and as a consequence of the Alabama affair still subsist, though at present dormant and dwindling.

It does not require the modern psychologist or M. Le Bon's analysis of the spirit of the crowd to show us how readily such latent states of feeling may in a moment of excitement be roused into conscious action and prove irresistible forces, just as we have seen religious passions, long slumbering, suddenly kindled into fury by apparently small incidents. Against such mass passions, reason has slim chance indeed.

The inevitable propriety of submitting to arbitration questions growing out of the interpretation of existing treaties seems obvious, yet it is some times questioned. As a treaty necessarily concerns both parties, its interpretation can by no possibility of law or logic be a mere domestic question.

In 1743 Spain and Great Britain embarked upon a disastrous war all over the alleged loss by a seaman named Jenkins of his ear. As Green pithily puts it: 
"The ill humor of the trading classes rose to madness in 1738, when a merchant captain named Jenkins told at the Bar of the Hrouse of Commons the tale of his torture by the Spaniards, and produced an ear which he said they had cut off with taunts at the English king. It was in vain that Walpole strove to do justice to both parties, and that he battled stubbornly against the cry for an unjust and impolitic war. But his efforts were in vain. His negotiations were foiled by the frenzy of one country and the pride of another."

Thus the war for Jenkins' ear was entered upon, despite the desires of the Government and England suffered reverses and tremendous loss in lives and money, all to no purpose. For even had Jenkins' story been true, it would hardly have justified a disastrous conflict between great nations, nor would it have restored to him the lost feature. But it is even probable that his tale was untrue, or greatly exaggerated. As Lecky tells the story (History of the I8th Century, Vol. 1, p. 416):

"The truth of the story is extremely doubtful, but the end that was aimed at was attained. The indignation of the people, fanned as it was by the press, and by the untiring efforts of all sections of the Opposition, became uncontrollable."

Here indeed was a war demanded by no national policy, induced by no particular oppression, for authoritative historians tell us that there was no serious violation of international law or right on the part of Spain toward England.

Such a conflict is an evidence of the fact that war may often be an avertable accident. Had there been a tribunal to which England might have adressed her plea on behalf of her unfortunate seaman, redress might easily have been found and the danger of public outburst averted.

The danger of war today comes from popular feeling. Give diplomacy time and opportunity and the danger of war will be minimized. No modern civilized people will allow themselves to be drawn into a war which they consider unjust. Hence, the assurance in advance that there is law and a forum to which the aggrieved may appeal side-tracks exhibitions of popular feeling at the outburst. It may not always avert war, just as the decision of the Supreme Court in the Dred Scot case could not avert our Civil War, but it will materially lessen its probability.

Yet, our War of 1812, the Mexican War, the late Spanish- 
American IIar, should have been so arerted. The popular excitement created by the destruction of the Maine, made it almost impossible for diplomacy to avoid the conflict. Popular feeling forced the hands of statesmen as it had done before, yet immediate submission of the question of Spain's responsibility to a rerecognized international tribunal might well have averted this popular outburst.

The history of arbitration is a gratifying story. Many disputes have been settled, much law has-been evolved, but more even has been done than that; in many cases an escape has been found from the coercive forces of popular sentiment, prejudice and inherited animosity, which, if left unappeased, might easily have led to conflict.

Commercial jealousies certainly have their part in bringing about war, but no-peoples consciously go to war for commercial gain. The causes are far deeper. If the sparks of popular passion, kindled by disputes over commercial matters, can be smothered at once, or never allowed to burst into flame, then war may often be averted and settlement reached through arbitration where international law is adequate, and in those comparatively rare instances where there is no law, through diplomatic dealings. But justice denied or delayed is the most fruitful source of human strife, both between individuals and among nations. The development of adequate law and the perfection of the mechanism of arbitration will accomplish far more substantial results than any mere expressions of laudable sentiments.

Frederic R. Coudert

New York, December, rora. 